\title{
A Study of the Relationship between Students' Views toward A Career Management Class and Their Future Careers
}

\author{
Dr. Evren Ayranci (Corresponding author) \\ Faculty of Economics and Administrative Sciences, Istanbul Aydin University \\ Tel: 90-532-405-4094Ｅ-mail: xonox@mynet.com \\ Dr. Ercan Oge \\ Faculty of Economics and Administrative Sciences, Istanbul Aydin University \\ Tel: 90-542-895-3299Ｅ-mail: ercanoge@anadolubil.edu.tr
}

\begin{abstract}
Today, the pursuit of professional career goals is a challenge and the best way to handle this challenge is through the accumulation of knowledge, skills, experience and vision regarding the job, which is all connected with the subject of career. Institutions of higher learning provide students with the necessary knowledge and skills. It is, however, important that students' awareness about the career itself be raised. In Turkey, this awareness is provided through career management classes. The purpose of this study is to identify the relationship between college students' views about the career management class and their views about their future careers. The authors of this study examined this relationship among students in a Turkish university. The results reveal that when students have more positive ideas about the career management class, they approach the issue of career more professionally, i.e., their enthusiasm for career planning increases, they show less hastiness about the future, they become more inclined to think that their future is not uncertain and they perceive that they are receiving adequate career support.
\end{abstract}

Keywords: Career, Management, Higher Education, Turkey

\section{Introduction}

It is striking that the issue of career management has become critical in today's competitive business environment, where traditional views of the career are beginning to change (Nabi \& Bagley, 1999). As competition in the business environment grows increasingly fierce, it is increasingly important that university students looking for work are well-informed. Therefore, institutions of higher learning that are preparing their students for the business world need to assume significant responsibilities when informing students about their careers.

Institutions of higher learning are responsible for more than just providing students with technical information and skills. These institutions must also ingrain in their students the awareness necessary for them to look for work, secure an appropriate job and move ahead in careers that best suit them. In brief, "career education" must be provided in terms of technical information, skills and awareness about what a career should be.

Therefore, the primary purpose of career education should be to provide individuals with information and awareness pertinent to the future of their careers. The "career management" concept is vitally important for today's youth as they have been motivated for their future careers without sufficient direction. The youth expect to receive a quality education and are extremely ambitious when it comes to advancing in their professional careers. According to the findings in a number of studies, however, it is evident that many young people do not have a consistent plan for achieving their goals for the future (Sagdic \& Demirkaya, 2009). For this reason, university graduates can be expected to face disappointment in the future regarding their careers.

As can be understood from the previous paragraph, the issue of a career is a topic that should be addressed not after students have embarked on a career, but when they are still in school. In general, the issues of "career planning" and "career management" are addressed with the assumption that the person will be a wage earner. (Note 1)

On the other hand, the introduction of career counseling for students in institutions of higher learning is remarkable. Practices of this sort help students who have completed their education and are embarking on a career to begin properly by assessing the needs of the market as well as their skills and abilities in a more realistic fashion.

\section{The concepts of career and career planning}

In recent years, numerous definitions have been put forward regarding the "career" concept in the world of business. Generally, a career is defined as "the achievement realized by a person in a job or the sum of all the work one has done throughout one's life" (Kitapci \& Sezen, 2002). A more detailed definition of the career concept encompasses the job experiences that a person has acquired throughout life (Simsek, Celik, \& Akatay, 2007). The career concept 
also pertains to the hierarchical positions a person has occupied in business life and the attitudes and behaviors related to these positions (Aytac, 2005).

Career management is a general concept that encompasses career planning and career development functions. It involves the design and application of the overall process that makes it possible to plan and manage careers in a way that meets the needs of the organization and the preferences and capacities of individuals (Simsek \& Oge, 2007). Per this definition, career planning and development are both components of career management.

Career planning involves the definition of what must be accomplished to identify a person's career goals and to attain those goals (Ozgen, Ozturk, \& Yalcin, 2005). Career development, on the other hand, makes it easier to achieve the career goals and objectives by providing employees the ability to evaluate and expand their skill set (Simsek et al., 2007).

As mentioned earlier, the issue of careers must be addressed when individuals are still students. Therefore, it would be appropriate to review studies that address the views regarding both career and career management among university students in the process of preparing for the business world.

\subsection{How university students view the issue of their careers}

If we focus on the views of Turkish students, a study conducted at Mehmet Akif Ersoy University by Sagdic and Demirkaya (2009) demonstrated that $88.4 \%$ of the students did not have future career plans related to their fields of study. The primary reasons were deficient foreign language education, lack of counselors and guides for career development, financial constraints and the desire to enter the workforce as soon as possible. In their study at Inönü University, Genc, Alim, and Genc (2007) demonstrated that when choosing a profession, the student's own desires were more important than guidance from their families or teachers, which did not have a significant impact. Furthermore, the study indicated that career guidance should be provided throughout the entire university experience. A similar study was conducted with students from Firat University Medical School, and the conclusion was that the most important factor in the choices of medical school students was their own desires $(63 \%)$, followed by the desires of their families (26.7\%) (Acik, Oguzoncul, Polat, Gungor, \& Gungor, 2002). In a study of the attitudes of students at Cerrahpaşa Medical School regarding medical education and post-graduation plans, Koksal et al. (1999) found that the most important factor in their choice of medicine as a profession was their own desires while the second most important factor was the desires of their families.

Studies conducted abroad have demonstrated that when individuals determine their own career path by balancing work, family and personal needs, it is easier for them to attain their career goals (Simonsen, 2000). In other words, individuals who have realistic career expectations and act accordingly are successful as long as they achieve balance (Greenhaus, Callanan, \& Godshalk, 2009).

The issues of "career expectation development" and "knowing oneself" mentioned in the previous paragraphs can surface even when an individual is a student. It is very important that university students plan their futures and their careers, which are a significant part of their future, or at least identify goals for the future. To appropriately plan and identify goals, students must have certain skills and information (Nabi and Bagley, 1999).

Classes provided at institutions of higher learning can give students these skills and information. These classes shape the students' expectations for the future and their careers. This is essential because studies have shown that most students do not think about their future very much, especially when it comes to career planning. For example, Lau and Pang (1995) conducted a study in Hong Kong on 492 students and learned that most of the students had not made plans for their future careers. Similarly, Doherty, Viney, \& Adamson (1997) noted that university students, especially those about to graduate, had not determined the course of their career and had a tendency to take whatever job was available. In a study conducted in England, Counsell (1996) demonstrated that when it came to determining a career path, families, close friends and the world views of the students had the greatest impact. However, students did not pay enough attention to the self-perceived skill level, competencies and needs pertaining to the job market. In summary, it appears that students are not sufficiently informed when it comes to determining a career path. Stewart and Knowles (2001) addressed the same problem, arguing that students should be provided education regarding career management, especially in institutions of higher learning.

Miller and Liciardi (2003) concluded that Australian university students viewed career management training as extremely valuable and that they began their careers better informed due to this training. In a study of wage earners who had recently graduated from a university, Sturges, Guest, Conway and Davey (2002) demonstrated that those who received career management training and determined their own career path based on the training acted in accordance with the aspects of career management recommended by their organizations and were more loyal to their organizations. 
When all of this research is summarized, we can reach the following general conclusions:

- University students are not very well informed with regard to their future careers.

- There are a number of factors that affect how students determine a career path.

- Information provided about career management can have a number of positive effects on students' careers.

\section{Methodology}

\subsection{The purpose, scope and importance of the research and the methodology used for data collection}

The purpose of this study is to examine the relationship between university students' views of career management classes and their views about their future careers. There are two main approaches that could be applied to conduct such a study. One approach is to compare the students' views before and after taking the career management class in a particular academic year. Another approach would be to compare the views of students who have not yet taken the career management class to those who already have.

For this study, the second approach was utilized. As a result, students were evaluated in two groups: those who had and those who had not taken the career management class. Subsequently, relationships between the students' view of the class and their career perspectives were examined.

The study included 142 students in the human resources management program at Istanbul Aydin University's Anadolu Bil Vocational College. There were a number of reasons for conducting the research in this program:

- This college provides a two-year program where the career management class is provided in the second year. As a result, it is easy to distinguish between those who have and have not taken the class (i.e. first-year vs. second-year students).

- The career management class is unique to the human resources management program in this vocational college. As a result, the sample is homogenous as it includes students from the same program.

- A characteristic of the human resources management program is that both first- and second-year students receive general career orientation. Therefore, even students who have not taken the career management class have a general understanding of the career concept.

The study is important in terms of Turkish literature on the subject. Even though there are studies that address the career planning and career expectations of students in various Turkish educational institutions, the authors could not find any research that examined the relationship between students' career views and career management classes. As was demonstrated in the previous section, only a few studies in the foreign literature examine this relationship. Therefore, this study can be viewed as contributing not only to the research in Turkey but also to the international literature on the subject.

A survey was utilized to collect data for this study. The survey was conducted at the end of spring semester of the academic year 2009-2010 (from June 15th to June 25th, 2010). It involved 243 students in the Human Resources Management Program at Istanbul Aydın University's Anadolu Bil Vocational College. The number of students who participated in the survey was 142 , indicating a participation rate of $58.5 \%$.

To determine the content of the survey, the previously mentioned studies from Turkey and other countries were reviewed and 28 statements were created with the assistance of these studies. All opinions regarding these statements were collected in a manner consistent with the five-point Likert scale. The literature demonstrates that students in institutions of higher learning are not well-informed regarding their careers and have pessimistic views of the future. This was taken into consideration in the process of creating the statements in the survey.

\subsection{Research findings}

\subsubsection{The statistical structure and reliability analyses of the statements}

The survey form contained a total of 28 statements for each of the 142 students. As a result, there were a total of 3976 data points. However, when the survey forms were examined, 26 data points were missing (0.65\%). An average value for the same type of data was used in place of each missing data point prior to analysis.

Some of the statements on the survey were related to the career management class, while others were related to careers. To understand what kind of structure was formed by these statements, an exploratory factor analysis was first conducted. More specifically, we were interested in how the statements in the survey were grouped in a statistically significant manner. An analysis of the resulting groups, as well as the reliability and relationship analysis between all the groups will be presented later. 
The varimax rotation method and principal component deduction method were used in the exploratory factor analysis. To reliably see the grouping of the statements, those with a factor load less than $|0.4|$ were not included.

The results of the analysis revealed a total of five statement groups (factors). The Kaiser-Meyer-Olkin (KMO) test value in the analysis was 0.727 , suggesting that the data were suitable for division into different groups. In the analysis, where a Bartlett test value of 5\% was significant, five factors accounted for $51.04 \%$ of the total variance. These five factors and their statements are given in Table 1.

According to Table 1, students' positive views about the career management class constituted a separate factor, encompassing a total of seven statements. In contrast, four factors were revealed regarding other perspectives on the career issue:

- Unenthusiastic about career planning

- Perception of lack of career support

- Hastiness and uncertainty about the future

- Perception of competency with regard to starting a career

As mentioned earlier, the survey contained 28 statements. At this stage, two statements were removed because of statistical inconsistencies. Therefore, the five factors contained a total of 26 statements as can be seen in Table 1 .

Table 2 contains the reliability analysis results with each separate factor and the Cronbach-Alpha values for all of the variables at the end.

In the literature, statements with a Cronbach-Alpha value of 0.6 or higher are generally taken into consideration; however, values of 0.5 or higher are also acceptable (Garson, 2008). Therefore, the statements for the "Perception of Competency Regarding a Career" factor were left out of the analysis. When the statements for these factors were excluded, the Cronbach-Alpha values of the remaining statements became 0.706.

The exploratory factor analysis and reliability analysis show that the views of students regarding the career management class constitute a statement. Another conclusion is that the views of students regarding the career management class are based on four principal aspects (factors). However, the reliability value of one of the four factors was unacceptably low.

Therefore, the views of students regarding the issue of career are based on three aspects: lack of enthusiasm for career planning, a perception that they lacked career support and hastiness and uncertainty regarding the future.

3.2.2 Relationships identified between aspects that shape the views of students regarding careers and their views toward the career management class

As discussed previously, the purpose of this study is to examine the relationships between the views of students regarding the career management class and aspects regarding the issue of career. The exploratory factor analysis revealed such aspects. The potential relationships between these aspects and their specific characteristics must be examined. The authors chose to use the structural equation modeling (SEM) to analyze these potential relationships.

In short, SEM is a method used to test and predict cause-effect relationships between variables and factors (variable groups). In this method, the relationships between variables and variable groups are first taken into account. Then, the relationships within the variable groups are addressed. A model that includes all of these relationships is developed and tested to see how realistic it is in light of the data obtained. Therefore, SEM is a method that is useful for conducting both holistic (in terms of the entire model) and individual (in terms of the relationships in the model) relationship analyses (Schumacker \& Lomax, 2004).

The fundamental characteristics of SEM are as follows (Danes, Rueter, Kwon, \& Doherty, 2002; The University of Texas at Austin, Division of Statistics and Scientific Computation, 2009):

- SEM is a combination of regression, correlation, covariance and factor analyses

- The primary assumption in SEM is that any model can be converted into a series of linear regression equations

Figure 1 shows the model addressing the relationships of the four factors that passed the reliability test. The model in Figure 1 is described as follows:

- The four factors are (each factor is indicated by an oval):

o PosV_CML: A positive view about career management classes;

o Un_CP: Unenthusiastic about career planning;

o Per_CS: Perception of a lack of career support; 
O HA_Fut: Hastiness and uncertainty about the future.

- It is assumed that there are relationships between all four factors

- The four factors encompass a total of 23 statements, with each rectangle representing a statement. The number in each rectangle shows the number of each statement in the questionnaire.

At this point, there is an issue that should be clarified. All of the data were used to obtain the four factors. However, when addressing the model in Figure 1, the data from the first- and second-year students were evaluated individually. In other words, the same model was generated and tested separately for the first- and second-year students. The expectation here was that the relationships between the factors created by the data from first- and second-year students would be different from each other.

The model used in the research is provided in Figure 1. Table 3 contains the goodness of fit indices that demonstrate how realistic the model is when it is based on the data from the first- and second- year students.

There are differing views regarding ideal values for the goodness of fit indices in Table 3, but when viewed in light of the ideal values that are generally accepted (Diamantopoulos \& Siguaw, 2000), models built using two different data sets (one from first- and one from second- year students) appear to be realistic.

The research specifically focused on the relationships between the four factors. As such, the correlation coefficients between the factors for the two models should also be provided. The correlation coefficients for the first-year students are shown in Table 4.

There is no correlation coefficient between the Perception of Lack of Career Support and Positive View of Career Management Classes factors in Table 4, because the relationship between these factors is statistically insignificant $(\mathrm{p}<0.05)$.

In Table 4, we see that:

- When first-year students reported having a more positive view of the career management class, the lack of enthusiasm these students had for career planning declined (with a correlation value of -0.16).

- Similarly, when they reported a more positive view regarding the career management class, the students displayed less uncertainty and hastiness about the future $(-0.30)$

- It is striking that the same powerful relationships exist between aspects related to the career issue. To explain more; when students think that they lack career support, they are less enthusiastic about career planning (0.75). Furthermore, if students behave hastily regarding the future and think that the future is uncertain, they exhibit an increasingly unenthusiastic attitude towards career planning (0.70). Finally, if students become hastier regarding the future and think that the future is more uncertain, they think that they have even less career support (0.69)

In Table 5, the same results are shown for the second-year students. There is no correlation coefficient between Hastiness and Uncertainty about the Future and the Positive View of Career Management Classes because a relationship of $5 \%$ was considered insignificant.

Table 5 reveals that:

- When second-year students have a positive view of the career management class, they become more enthusiastic about career planning $(-0.22)$. Furthermore, there is an inverse relationship between this positive view and the perception of a lack of career support.

- The same relationships can be seen among aspects related to the career issue. The weakest relationship is between the perceived lack of career support and a lack of enthusiasm for career planning (0.24). The strongest relationship is between the students' hastiness/perception of the future being uncertain and their lack of enthusiasm for career planning (0.61).

\section{Conclusion}

This research has achieved a number of results. Various statements were used to understand students' views on career management. Seven of these statements constitute a factor (group). The first striking result was that this factor included completely positive statements regarding the career management class. In other words, statements that contained only positive sentiments regarding the career management class formed a separate factor. This factor was called the Positive View about Career Management Classes.

Views about the career issue were divided into three factors that were statistically significant. All of these factors were clearly negative. Specifically, it is striking that the students' perspectives on the career issue were negative. This conclusion is similar to the general conclusions found in the literature. 
The relationships of the four factors were modeled. The research model in Figure 1 was built up twice, first with the data from first-year students and then with the data from second-year students. The models using data from both the first- and second-year students proved to be statistically realistic. Therefore, it is clear that both first- and second-year students have similar ideas in terms of the relationships between their career views and their views of the career management classes.

Furthermore, the lack of enthusiasm for career planning evidenced by the students who participated in the survey, the view that they lacked career support, their hastiness about the future and the perception of an uncertain future all changed in the same direction. In short, all of the aspects that shaped the students' perspectives regarding careers varied in a similar fashion.

The primary conclusion reached with regard to the purpose of the study is that a positive view of the career management class had an inverse relationship with aspects related to the issue of career. Consequently, when students have a more positive view of the career management class in general, it can be argued that they are more enthusiastic about career planning, they do not think they are as deprived of career support, they tend to be less hasty in their behavior about the future and they do not think that the future is so uncertain.

On the other hand, there are a number of important issues related to this primary result. There is an important difference between the views of first- and second-year students. First-year students did not exhibit a significant relationship between a positive view of the career management class and the idea that they lack career support. Second-year students, on the other hand, did not exhibit a significant relationship between having a positive perspective about the same class and behaving hastily regarding an uncertain future. Therefore, first- and second-year students displayed a tendency to relate the career management class to different aspects of their careers.

The relationship between the first-year students' positive views of the career management class and their lack of enthusiasm for career planning turned out to be weaker than the same relationship from the second-year students. A possible reason for this result may be that the first-year students had not yet taken the class. In other words, because the second-year students took the class, they may be able to defend the positive contribution of this class on career planning in a more powerful way. Another possible reason could be the approaching graduation of second-year students. Second-year students expect to enter the workforce soon and may view career planning as more important than first-year students. For this reason, second-year students may think that the career management class is more important for their careers.

Another result is that second-year students think that they lack career support, but that the career management class reduced this feeling of deprivation. In contrast, there was no such result with the first-year students. As was indicated in the previous paragraph, second-year students are expected to enter the workforce in a short period of time. Therefore, this could be interpreted as second-year students feeling a greater need for career support compared to first-year students. Second-year students may have viewed the career management class as having helped to meet this need.

The final result is that the first-year students are in more of a hurry to start their careers and are more likely to think that the future is uncertain, while believing that the career management class will be helpful in alleviating this uncertainty and hastiness.

As expected, the career management class was shown to be related to the ways in which students viewed the larger career issue. A more positive view of the career management class mitigated other negative aspects of the career issue.

Though other Turkish studies have examined the general issues of career perspectives among students, they have not focused on specific aspects related to the career issue. Future studies could focus on how career views are related to a variety of specific elements. Some of these issues include students' world views, family characteristics and the overall psychological make-up. Because students are in academic institutions, it would be reasonable to examine the effects of education on students' views toward their future careers, as was the case in this study. Future studies could address the relationships between students' views of career and the career-related information they have received in different scientific branches of study. Another approach might be to study how the students' views of career-related classes influence their career expectations using attitude scales. Yet another approach might be to research the relationships between students' grades in career-related classes and their ideas about careers. Other approaches could examine all of these relationships over time. For example, a study might evaluate, at regular intervals, students' views of career management in their first year as students and later at graduation. Finally, their views of career and career management could be studied during a specific period in their careers. Research that examines how these views change over time would be an original study, at least in terms of Turkish literature. In conclusion, a number of different studies including students and the issue of career management could be conducted. 


\section{References}

Acik, Y., Oguzoncul, F., Polat, A., Gungor, Y., \& Gungor, L. (2002). Firat Üniversitesi Tıp Fakültesi Öğrencilerinin Tıp Eğitimi ve Mezuniyet Sonrası Hakkındaki Düşünceleri [The thoughts of the medical students of Firat University about medical education and post-graduation]. Toplum ve Hekim, 17, 189-194.

Aytac, S. (2005). Çalış̧a Yaşamında Kariyer Yönetimi, Planlaması, Gelişimi ve Sorunları [Career management, planning, development and problems in work life] (2nd ed.). Bursa, Turkey: Ezgi Publications.

Barutcugil, I. (2010). Kariyer Planlama ve Kariyer Yönetimi [Career planning and career management]. [Online] Available: http://www.ikademi.com/kariyer-planlama/749-kariyer-planlama-ve-kariyer-yonetimi.html (July 12, 2010).

Counsell, D. (1996). Graduate career in the UK: An examination of undergraduates' perceptions. Career Development International, 1, 34-41.

Danes, S. M., Rueter, M. A., Kwon, H-K., \& Doherty, W. (2002). Family FIRO model: An application to family business. Family Business Review, 15, 36-40.

Diamantopoulos, A. \& Siguaw, J. A. (2000). Introducing LISREL. London: Sage Publications.

Doherty, N., Viney, C., \& Adamson, S. (1997). Rhetoric of reality: Shifts in graduate career management? Career Development International, 2, 173-179.

Garson, G. D. (2008). Scales and standard measures. (2008). [Online] Available: http://faculty.chass. ncsu.edu/garson/PA765/standard.htm\#internal (July 13, 2010).

Genc, G., Kaya, A., \& Genc, M. (2007). İnönü Üniversitesi Tıp Fakültesi Öğrencilerinin Meslek Seçimini Etkileyen Faktörler [The factors that affect the occupation choices of Inonu University medical students]. İönü Üniversitesi Ĕ̈itim Fakültesi Dergisi, 8, 49-63.

Greenhaus, J. H., Callanan, G. A. \& Godshalk, V. M. (2009). Career management (4th ed.). Thousand Oaks, CA: Sage Publications.

Kitapcı, H., \& Sezen, B. (2002). Çalışanların Tatminini Belirleyici Unsurlar Üzerine Bir Araştırma. Kariyer Süreci Örneği [A research on the factors determining workers' satisfaction. The sample of career process]. Firat Üniversitesi Sosyal Bilimler Dergisi, 12, 219-230.

Koksal, S., Vehid, S., Tunckale, A., Cercel, A., Erginoz, E., Kaypmaz, A. \& Ozbal, A. N. (1999). Cerrahpaşa Tip Fakültesi Öğrencilerinin Tıp Eğitimi ve Mezuniyet Sonrasına İlişkin Tutumları [The attitudes of Cerrahpasa medical students about medical education and post-graduation]. Cerrahpaşa Tip Dergisi, 30, 251-258.

Lau, A., \& Pang, M. (1995). Undergraduates' career perceptions and first jobs needs in Hong Kong. The International Journal of Career Management, 7, 14-24.

Miller, S. \& Liciardi, R. (2003). Tertiary student perceptions of the benefits of professional career management education: An exploratory study. Career Development International, 8, 309-315.

Nabi, G. R. \& Bagley, D. (1999). Graduates' perceptions of transferable personal skills and future career preparation in the UK. Education + Training, 41, 184-193.

Ozgen, H., Ozturk, A. \& Yalcin, A. (2005). Insan Kaynakları Yönetimi [Human resources management]. Adana,Turkey: Nobel Publications.

Sagdic, M. \& Demirkaya, H. (2009). Üniversite Öğrencilerinin Kariyer Gelişim Planlarına İlişkin Yaklaşımları [The views of university students about career development plans]. Erciyes Üniversitesi Sosyal Bilimler Enstitüsü Dergisi, $26,233-246$.

Schermelleh-Engel, K., Moosbrugger, H. \& Müller, H. (2003). Evaluating the fit of structural equation models: Tests of significance and descriptive goodness-of-fit measures. Methods of Psychological Research Online, 8, $31-51$

Schumacker, R. E. \& Lomax, R. G. (2004). A beginner's guide to structural equation modeling (2nd ed.). Mahwah, NJ: Lawrence Erlbaum Associates Inc.

Simonsen, P. (2000). Career compass: Navigating your career strategically in the new century. Palo Alto, CA: Davies-Black Publishing.

Stewart, J. \& Knowles, V. (2001). Graduate recruitment: Implications for business and management courses in HE. Journal of European Industrial Training, 25, 98-108. 
Sturges, J., Guest, D., Conway, N. \& Davey, K. M. (2002). A longitudinal study of the relationship between career management and organizational commitment among graduates in the first ten year at work. Journal of Organizational Behavior, 23, 731-748.

Simsek, M. S., Celik, A. \& Akatay, A. (2007). Kariyer Yönetimi ve Insan Kaynakları Yönetimi Uygulamaları [Applications of career management and human resources management] (2nd ed.). Ankara, Turkey: Gazi Publications.

Simsek, M. S. \& Oge, H. S. (2007). Stratejik ve Uluslar Arası Boyutlarlyla İnsan Kaynakları Yönetimi [Human resources management with strategic and international dimensions]. Ankara, Turkey: Gazi Publications.

The University of Texas at Austin, Division of Statistics and Scientific Computation. Frequently asked questions and answers. [Online] Available: http://ssc.utexas.edu/software/faqs/general (July 13, 2010).

\section{Notes}

Note 1. See Barutcugil, I., Career Planning and Career Management, http://www.ikademi.com/kariyer-planlama/749-kariyer-planlama-ve-kariyer-yonetimi.html, (2010), for an example of a study that defines career planning and assumes that the individual is a wage-earner. (Access date: 12 July 2010).

Note 2. The leading suitability indices in the literature are provided in Table 3. For definitions of these indices and other goodness of fit indices see: Schermelleh-Engel, K., Moosbrugger, H., and Müller, H., Evaluating the fit of structural equation models: Tests of significance and descriptive goodness-of-fit measures, Methods of Psychological Research Online, Vol. 8, No. 2, 31-51, 2003.

Table 1. Factors Determined by the Exploratory Factor Analysis

\begin{tabular}{|c|c|c|c|c|c|}
\hline & \multicolumn{5}{|l|}{ Factor } \\
\hline & $\begin{array}{l}\text { Positive view } \\
\text { about career } \\
\text { management } \\
\text { classes }\end{array}$ & $\begin{array}{l}\text { Unenthusiastic } \\
\text { about } \\
\text { career planning }\end{array}$ & $\begin{array}{l}\text { Perception of } \\
\text { lacking career } \\
\text { support }\end{array}$ & $\begin{array}{l}\text { Hastiness and } \\
\text { uncertainty } \\
\text { about the } \\
\text { future }\end{array}$ & $\begin{array}{l}\text { Perception of } \\
\text { competency with } \\
\text { regard to starting } \\
\text { a career }\end{array}$ \\
\hline $\begin{array}{l}\text { It is helpful to have a special class called "career management" to } \\
\text { address career issues. }\end{array}$ & .860 & & & & \\
\hline $\begin{array}{l}\text { I think that I will be able to determine more clearly what jobs I can } \\
\text { perform as a result of the career management class. }\end{array}$ & .856 & & & & \\
\hline $\begin{array}{l}\text { I think that the career management class will make me better } \\
\text { informed about my profession. }\end{array}$ & .844 & & & & \\
\hline $\begin{array}{l}\text { The career management class helped / will help me think more about } \\
\text { my future. }\end{array}$ & .809 & & & & \\
\hline $\begin{array}{l}\text { The career management class will affect my career development } \\
\text { after I embark on my career. }\end{array}$ & .804 & & & & \\
\hline $\begin{array}{l}\text { I think that I have been / will be less afraid of embarking on a career } \\
\text { because of the career management class. }\end{array}$ & .773 & & & & \\
\hline $\begin{array}{l}\text { The career management class that I took / will take will increase my } \\
\text { chances of finding a job. }\end{array}$ & .755 & & & & \\
\hline $\begin{array}{l}\text { I have a negative view toward career planning because I do not think } \\
\text { that there is a financial advantage to having a career in my country. }\end{array}$ & & .604 & & & \\
\hline $\begin{array}{l}\text { I cannot find much time for career planning because I am enthralled } \\
\text { with school life, entertainment and vacations. }\end{array}$ & & .591 & & & \\
\hline $\begin{array}{l}\text { There may be unexpected developments when I enter business world } \\
\text { after graduation, so it seems more reasonable to plan my career in } \\
\text { the future. }\end{array}$ & & .576 & & & \\
\hline $\begin{array}{l}\text { I think that the lives of students who prepare or want to prepare a } \\
\text { career development plan will be very ordinary. }\end{array}$ & & .535 & & & \\
\hline $\begin{array}{l}\text { I think that the job situations for individuals who have a career in } \\
\text { our field are not good and therefore it would be better to wait before } \\
\text { identifying career goals. }\end{array}$ & & .531 & & & \\
\hline
\end{tabular}




\begin{tabular}{|c|c|c|c|c|}
\hline $\begin{array}{l}\text { I will only plan my future after I finish school and if I pass the KPSS } \\
\text { or private sector entry-level hiring exams. }\end{array}$ & .520 & & & \\
\hline $\begin{array}{l}\text { If I knew that I would have a good job and enough money when I } \\
\text { have a career, then I would make a career plan. }\end{array}$ & .423 & & & \\
\hline $\begin{array}{l}\text { I do not think that the education I received from school is sufficient } \\
\text { for me to have a career. }\end{array}$ & & .715 & & \\
\hline $\begin{array}{l}\text { School will be completed before we can decide what we want to do } \\
\text { in the future. }\end{array}$ & & .695 & & \\
\hline $\begin{array}{l}\text { I do not believe that I can find a job related to my profession after I } \\
\text { graduate. Therefore, I think that career expectations for the future } \\
\text { will not be fulfilled. }\end{array}$ & & .621 & & \\
\hline $\begin{array}{l}\text { I only receive some of the help that I need regarding career planning } \\
\text { and the implementation of this plan for the future. }\end{array}$ & & .503 & & \\
\hline $\begin{array}{l}\text { Because I have been influenced by opinions that state it is very } \\
\text { difficult to have a career in my field, I do not think that I will be } \\
\text { successful at having and developing a career. }\end{array}$ & & .470 & & \\
\hline I want to begin making money right away even if it is not that much. & & & .735 & \\
\hline $\begin{array}{l}\text { My number one goal is to get a job and become financially } \\
\text { independent. I am considering preparing a career plan after I enter } \\
\text { the workforce. }\end{array}$ & & & .651 & \\
\hline $\begin{array}{l}\text { I have no plan for the future in my field. It was not my desire to } \\
\text { study in this field but my family's. }\end{array}$ & & & .537 & \\
\hline $\begin{array}{l}\text { I think that the tests necessary to have a career (Foreign Language, } \\
\text { GPA, Transfer Exam) are too difficult. }\end{array}$ & & & .433 & \\
\hline $\begin{array}{l}\text { I am hesitant to plan my career because I lack information, skill or } \\
\text { self-confidence. }\end{array}$ & & & & .801 \\
\hline $\begin{array}{l}\text { I am hesitant to plan my career because I do not know exactly what } \\
\text { my strengths and weaknesses are. }\end{array}$ & & & & .673 \\
\hline $\begin{array}{l}\text { It is the influential professional networking capability more than } \\
\text { professional competency or career planning that leads to career } \\
\text { success. }\end{array}$ & & & & -.464 \\
\hline
\end{tabular}

Table 2. Results of the Reliability Analyses

\begin{tabular}{|c|c|}
\hline Factor & Cronbach-Alpha Values \\
\hline Positive view about career management classes & 0.922 \\
\hline Unenthusiastic about career planning & 0.652 \\
\hline Perception of lack of career support & 0.657 \\
\hline Hastiness and uncertainty about the future & 0.555 \\
\hline Perception of competency with regard to starting a career & 0.386 \\
\hline ALL STATEMENTS OF THE FACTORS & $\mathbf{0 . 7 3 6}$ \\
\hline
\end{tabular}

Table 3. The Goodness of Fit Index Values from the Models Built with the Data from the First- and Second-Year Students

\begin{tabular}{|c|c|c|}
\hline Goodness of Fit Indices (Note 2) & $\begin{array}{c}\text { Model Containing Data from } \\
\text { First-Year Students }\end{array}$ & $\begin{array}{c}\text { Model Containing Data from } \\
\text { Second-Year Students }\end{array}$ \\
\hline Root Mean Square Error of Approximation (RMSEA) & 0.071 & 0.087 \\
\hline Goodness of Fit Index (GFI) & 0.87 & 0.90 \\
\hline Standardized Root Mean Square Residual (SRMSR) & 0.12 & 0.11 \\
\hline Comparative Fit Index (CFI) & 1.00 & 0.98 \\
\hline
\end{tabular}


Table 4. The Relationships between the Factors in the Model that Included Data from the First-Year Students

\begin{tabular}{|c|c|c|c|c|}
\hline & $\begin{array}{c}\text { Positive View About } \\
\text { Career Management } \\
\text { Classes }\end{array}$ & $\begin{array}{c}\text { Unenthusiastic about } \\
\text { Career Planning }\end{array}$ & $\begin{array}{c}\text { Perception of Lack of } \\
\text { Career Support }\end{array}$ & $\begin{array}{c}\text { Hastiness and } \\
\text { Uncertainty about the } \\
\text { Future }\end{array}$ \\
\hline $\begin{array}{c}\text { Positive View About Career } \\
\text { Management Classes }\end{array}$ & $\mathbf{1 . 0 0}$ & & & \\
\hline Unenthusiastic about Career Planning & $\mathbf{- 0 . 1 6}$ & $\mathbf{1 . 0 0}$ & $\mathbf{1 . 0 0}$ & \\
\hline $\begin{array}{c}\text { Perception of Lack of Career Support } \\
\text { Hastiness and Uncertainty about the } \\
\text { Future }\end{array}$ & -- & $\mathbf{0 . 7 5}$ & $\mathbf{0 . 6 9}$ & $\mathbf{0 . 7 0}$ \\
\hline
\end{tabular}

Table 5. The Relationships between the Factors in the Model that Included Data from the Second-Year Students

\begin{tabular}{|c|c|c|c|c|}
\hline & $\begin{array}{c}\text { Positive View About } \\
\text { Career Management } \\
\text { Classes }\end{array}$ & $\begin{array}{c}\text { Unenthusiastic about } \\
\text { Career Planning }\end{array}$ & $\begin{array}{c}\text { Perception of Lack of } \\
\text { Career Support }\end{array}$ & $\begin{array}{c}\text { Hastiness and } \\
\text { Uncertainty about the } \\
\text { Future }\end{array}$ \\
\hline $\begin{array}{c}\text { Positive View About Career } \\
\text { Management Classes }\end{array}$ & $\mathbf{1 . 0 0}$ & & & \\
\hline $\begin{array}{c}\text { Unenthusiastic about Career } \\
\text { Planning }\end{array}$ & $\mathbf{- 0 . 2 2}$ & $\mathbf{1 . 0 0}$ & $\mathbf{1 . 0 0}$ & \\
\hline $\begin{array}{c}\text { Perception of Lack of Career } \\
\text { Support }\end{array}$ & $\mathbf{- 0 . 1 3}$ & $\mathbf{0 . 2 4}$ & $\mathbf{0 . 5 8}$ & $\mathbf{1 . 0 0}$ \\
\hline $\begin{array}{c}\text { Hastiness and Uncertainty } \\
\text { about the Future }\end{array}$ & -- & $\mathbf{0 . 6 1}$ & & \\
\hline
\end{tabular}
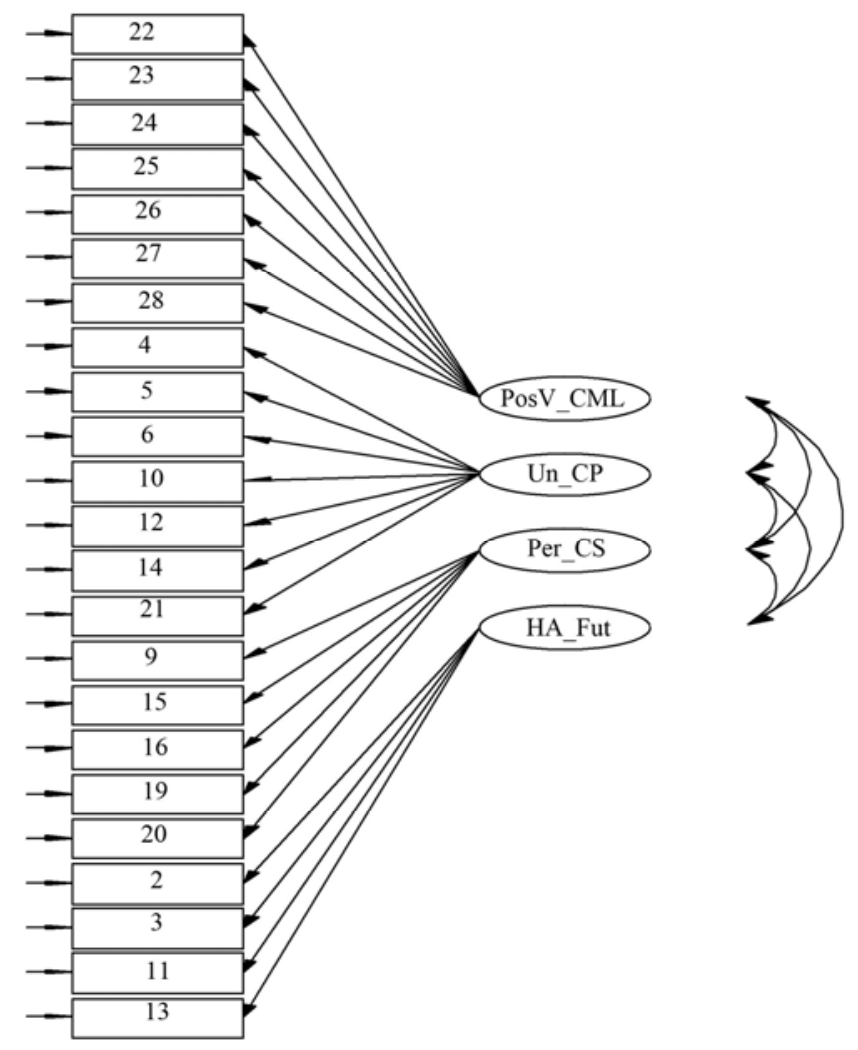

Figure 1. The Research Model 